\title{
Nanotechnology: Future of Environmental Air Pollution Control
}

\author{
Elham F. Mohamed (Corresponding author) \\ Air Pollution Department, Division of Environmental \\ Research National Research Centre, 33 EL Bohouth St., Dokki, Giza, P.O.12622, Egypt \\ Tel: 202-3371362Ｅ-mail: elham_farouk0000@yahoo.com
}

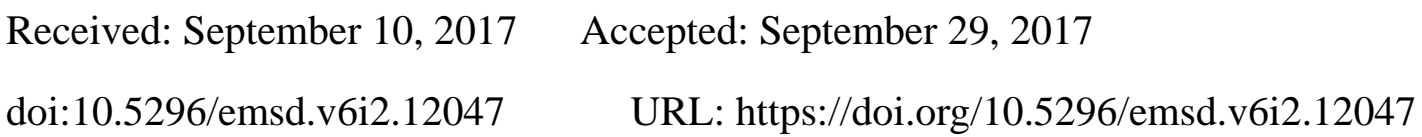

\begin{abstract}
Environmental contamination is one of the important issues that the world is confronting today, and it is expanding with each passing year and leading to grave and harmful effect to the earth. At present, the air contains various pollutants like CO, chlorofluorocarbons, volatile organic compounds, hydrocarbons, and nitrogen oxides. Water and soil are also contaminated with organic and inorganic compounds, the major sources for water and soil contamination are sewage water, industrial effluents, random use of pesticides, fertilizers, and oil spills. In parallel, the rapid growth of nanotechnology has gained a great deal of interest in the applications of nanomaterials potential in improved systems for monitoring and cleanup including all the three phases of environment. It can develop the pollutants sensing and detection and help in the improvement of novel remediation technologies. Nanomaterials are excellent adsorbents, catalysts and sensors due to their large specific surface areas and high reactivates. This review firstly sheds the light on the definition of nanoparticles, and the nanotechnology concept, the fundamental properties, classification, and fields of nanotechnology applications. Then it focuses broadly on the application of nanotechnology in environmental fields, in particular, its application in air pollution monitoring and remediation and its future trend in this field.
\end{abstract}

Keywords: Nanotechnology, Environmental fields, Air pollution, Monitoring, Remediation

\section{Introduction}

The term of nanotechnology (NT) was first proposed by Richard Feynman in 1959. Feynman described a process in which scientists would be able to use and control single atoms and molecules. Over a decade later, in his explorations of ultraprecision machining, Professor Norio Taniguchi invented the concept NT. It wasn't until 1981, with the development of the 
scanning tunneling microscope that could "see" single atoms, that new nanotechnology started (Hulla et al., 2015). The term NT composed from two words: the Greek numerical prefix nano referring to a billionth and the word technology is a generic term used to describe processes for the fabrication and / or usage of nanoscale structures (Sattler, 2010; Logothetidis, 2012). The advantage of working on this scale is that the elements possess properties completely different from those they would have on the normal scale or see their properties reinforced and actually have new physico- chemical characteristics (Hussain et al., 2015). These changes in physico-chemical characteristics allow development in a whole range of fields: health, industry, environment, energy, etc. Today, NT is one of the new scientific fields since it incorporates knowledge from the different fields of Informatics, Physics, Medicine, Biology, Engineering, and Chemistry (ISO, 2010). NT is emerging technology owing to the possibility to advance well-established materials and to produce novel products with totally new properties and functions with enormous potential in a wide range of applications (Sattler, 2010; Logothetidis, 2012; INPI, 2009).Manufactured nanomaterials present physicochemical, superficial and optical electronic properties, which solve difficult problems that can not be treated with conventional technologies. It plays an essential role in the development of innovative methods to create novel products, to replace existing tools and to produce new materials and chemicals with high performance and less consumption of energy (Logothetidis, 2012; Ramsden , 2013; Srivastava et al., 2015).The continuing propagation of industrial and civilization activities minimize the natural resources and in addition create a lot of dangerous wastes which cause environmental contamination (air, water, and soil) and hence menace human public health and the ecological security. The produced wastes include air contaminants; toxic gases ( $\mathrm{NO}, \mathrm{SO}_{2}, \mathrm{CO}_{2}, \mathrm{O}_{3}$, etc.), suspended particles, and other organic compounds. These environmental pollutants have a harmful effect on the human health, when entered the body by ingestion, absorption or inhalation. In addition, an increase in the temperature of the Earth and oceans change the Earth's climate causing a global warming. This is due to the excess overloading our atmosphere with greenhouse toxic gases (McMichael et al., 2003). Therefore, there is an urgent need to new technologies more efficient and economic to detect and correctly treat toxic environmental pollutants. Nanotechnology gives new solution for cleaning environment and improving the performance of traditional technologies (Adeleye et al., 2016). This innovation is additionally investigated for controlling contamination by reducing the release or preventing the pollutants formation.

\section{Nanotechnology}

Nanotechnologies are referred to the design, characterisation, production and application of structures, devices and systems by changing shape and size at the nanometre scale.

\subsection{Definition of Nanoparticles}

Nanoparticle possesses at least one dimension of 1 to $100 \mathrm{~nm}$ (ISO, 2010). Particles have diameter less than $100 \mathrm{~nm}$ exhibit new size-dependent properties compared with the bulk material. Nanomaterials with unique properties allow completely new applications to be found. There are several engineered nanomaterials such as carbon nanotubes, nanocomposites, 
quantum dots, fullerenes, quantum wires, and nanofibers (Georgakilas et al., 2015). Today, a very broad range of commercial products exist already in the market, including metals, ceramics, polymers, smart textiles, cosmetics, sunscreens, electronics, paints and varnishes. Nanomaterials are therefore purposely manufactured by humans to achieve the specific characteristics of materials at the nanometric scale. On the other hand, there are also natural nanoparticles: for example, erosion dust or volcanic eruption dust or marine spray. Other nanoparticles are produced unintentionally during combustion phenomena: for example, when burning wood or burning diesel engines (Wagner et al., 2014).

\subsection{Fundamental Properties}

Nanomaterials have unique properties particularly because of the nanoscale features. Nanoparticles can exhibit totally novel characteristics due to their high surface/volume ratio which make them more reactive than bulk forms of the same materials (Mukherjee, 2016).

A material (e.g. a metal) when in a nano-sized form can show properties which are totally different from those when the same material is in a non nano form. The nanomaterial will manifest different physicochemical properties when its size decreased (Mukherjee, 2016; Gillett, 2002). Elemental characteristics can change rather markedly at the nanoscale range: some change color, some get better at conducting heat or reflecting light, some become stronger, and some change or enhance magnetic properties (Hochella and Madden, 2005). Certain plastics at the nanometer range have the strength of steel. Tennis racquet manufactures already utilize nano-silicon dioxide crystals to improve equipment performance (Nanowerk , 2013; Heera and Shanmugam, 2015).The unique properties of these nanosized materials have advantages for several applications in various fields like biomedicine, pharmaceuticals, cosmetics, and environment (Loos , 2015).

\subsection{Classification of Nanoparticles}

Nanoparticles are mainly classified into four types (Fig.1) (Tiwari et al., 2013).

1. Zero- dimensional (OD) nanostructures: In this, all of the three dimensions are in the nano metric range. Ex. Nano particles or well separated nano powders.

2. One- dimensional (1D) nanostructure: In this, two dimensions are in the nano metric range and third dimension remains large. These structures have shape like rods. Ex. Nano tubes, Nano rods etc.

3. Two- dimensional (2D) nanostructure: In this, only one dimension is in the nano metric range while other two dimensions remain large. These display plane like structures. Ex. Nano thin films, Nano coating, Nano layers etc.

4. Three- dimensional (3D) nanostructure: In this, all three dimensions are outside the nano metric size range. It may consist of group of nano wires, nano tubes, or different distribution of nano particles. 


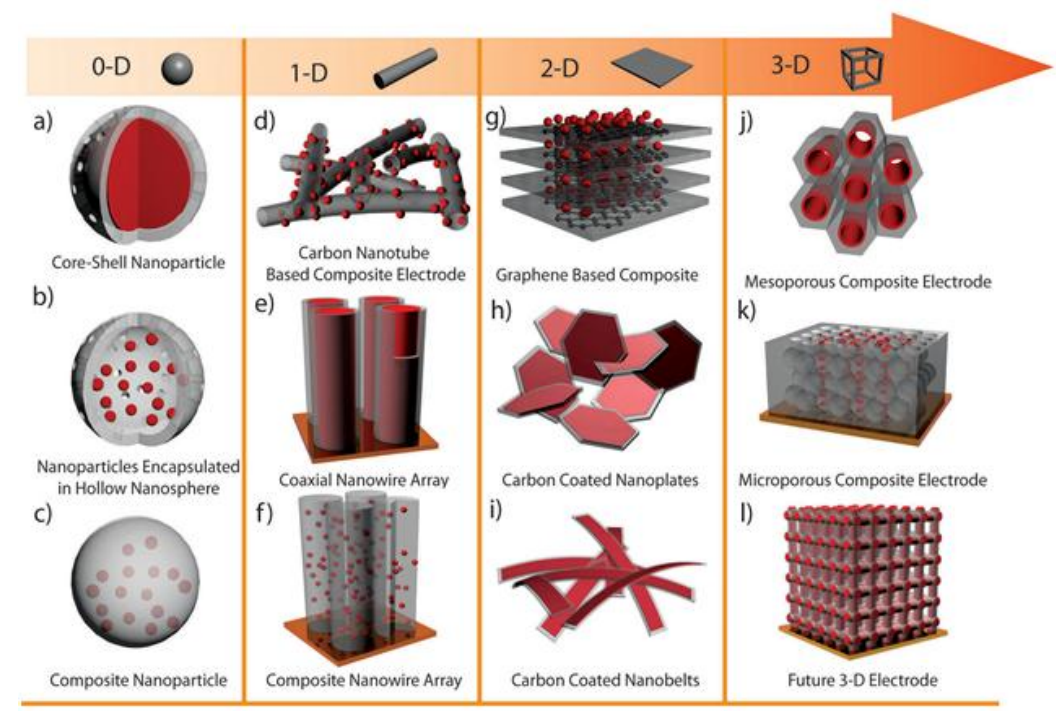

Figure 1. Nanomaterials are categorised according to their dimension

(Source: Tiwari et al., 2013)

\section{Application Areas of Nanotechnology}

Nanotechnology is fueling a revolution in manufacturing and production, creating new materials used in a variety of different fields, such as cosmetic, pharmaceutical, energy, catalytic materials, and environmental applications (Sattler, 2010; Logothetidis, 2012; INPI, 2009).Due to the great potential of this technology, there has been a worldwide increase in nanotechnology research investment. Some potential applications are mentionned in Table 1 (INCID, 2008).

Table 1. Nanotechnology areas of applications (Source: INCID, 2008)

\begin{tabular}{ll}
\hline Areas & \multicolumn{1}{c}{ Applications } \\
\hline Automotive & Lightweight construction; Catalysts; Painting; Tires; Sensors; Windshield and body coatings \\
\hline Construction & Materials; Insulation; Flame retardants; Surface coatings; Mortar \\
\hline Electronics & $\begin{array}{l}\text { Displays; Data memory; Laser diodes; Fiber optics; Optical switches; Filters; Conductive } \\
\text { coatings; Antistatic coatings; Transistors }\end{array}$ \\
\hline Engineering & Protective coatings for tools, machines; Lubricant-free bearings \\
\hline Food and Drink & Packaging; Storage life sensors; Additives; Juice clarifiers \\
\hline Medicine & $\begin{array}{l}\text { Drug delivery systems; Contrast medium; Rapid testing systems; Prostheses and implants; } \\
\text { Antimicrobial agents; In-body diagnostic systems }\end{array}$ \\
\hline Textiles & Surface coatings; "Smart" clothes (anti-wrinkle, stain resistant, temperature controlled) \\
\hline Chemical & Fillers for paints; Composite materials; Impregnation of papers; Adhesives; Magnetic fluids \\
\hline Cosmetics & Sunscreen; Lipsticks; Skin creams; Toothpaste \\
\hline Energy & Lighting; Fuel cells; Solar cells; Batteries; Capacitors \\
\hline Environmental & $\begin{array}{l}\text { Environmental monitoring; Soil and groundwater remediation; Toxic exposure sensors; Fuel } \\
\text { changing catalysts; Green chemistry }\end{array}$ \\
\hline Household & Ceramic coatings for irons; Odor removers; Cleaners for glass, ceramics, metals \\
\hline Sports & $\begin{array}{l}\text { Ski wax; Tennis rackets; Golf clubs; Tennis balls; Antifouling coatings for boats; } \\
\text { Antifogging coatings for glasses, goggles }\end{array}$ \\
\hline Military & Neutralization materials for chemical weapons, bullet-proof protection \\
\hline
\end{tabular}




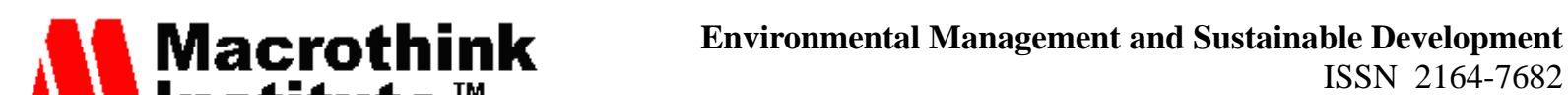 \\ 2017, Vol. 6, No. 2}

\section{Nanotechnology in Environmental Applications}

Extensive industrial and agricultural activities are the main causes for the contamination of the soil, water and air at all levels (McMichael et al., 2003; Khan et al., 2014). Environmental contamination is one of the important issues that the world is confronting today, and it is expanding with each passing year and leading to grave and harmful effect to the earth. At present, the air contains various pollutants like $\mathrm{CO}$, chlorofluorocarbons, volatile organic compounds, hydrocarbons, and nitrogen oxides. Water and soil are also contaminated with organic and inorganic compounds, the major sources for water and soil contamination are sewage water, industrial effluents, random use of pesticides, fertilizers, and oil spills (Khan et al., 2014; Das et al., 2015; Krug, 2009; Bhawana and Fulekar, 2012).Several traditional technologies have been already used to remediate all types of organic and toxic waste by adsorption, bio-oxidation, and chemical oxidation. In parallel, the rapid growth of nanotechnology has gained a great deal of interest in the applications of nanomaterials potential in improved systems for monitoring and cleanup including all the three phases of environment (Fig. 2) (Singh and Naveen, 2014). It can develop the pollutants sensing and detection and help in the improvement of novel remediation technologies. Nanomaterials are excellent adsorbents, catalysts and sensors due to their large specific surface areas and high reactivities. Some nanotechnology applications are nearly commercialized: nanosensors and nanoscale coatings to replace thicker, more wasteful polymer coating that prevent corrosion, nanosensors for dectection of aquatic toxins, nanoscale biopolymers for improved decontamination and recycling of heavy metals, nanostructured metals that break down hazardous organics at room temperature, smart particles for environmental monitoring and purification, and nanoparticles as novel photocatalyst for environmental cleanup (Khan et al., 2014; Das et al., 2015; Krug, 2009; Bhawana and Fulekar, 2012; Mehndiratta et al., 2013; Falahi and Abbasi, 2013; Chirag, 2015). It should be mentioned that due to the high variety of nanosystems techniques used for environmental treatment by several authors, so these are only summarized in the form of tables (Table 2) (Mansoori et al., 2008; Singh and Naveen, 2014) and we will focus in the next section on the nanotechnologies and applications in air pollution sector.

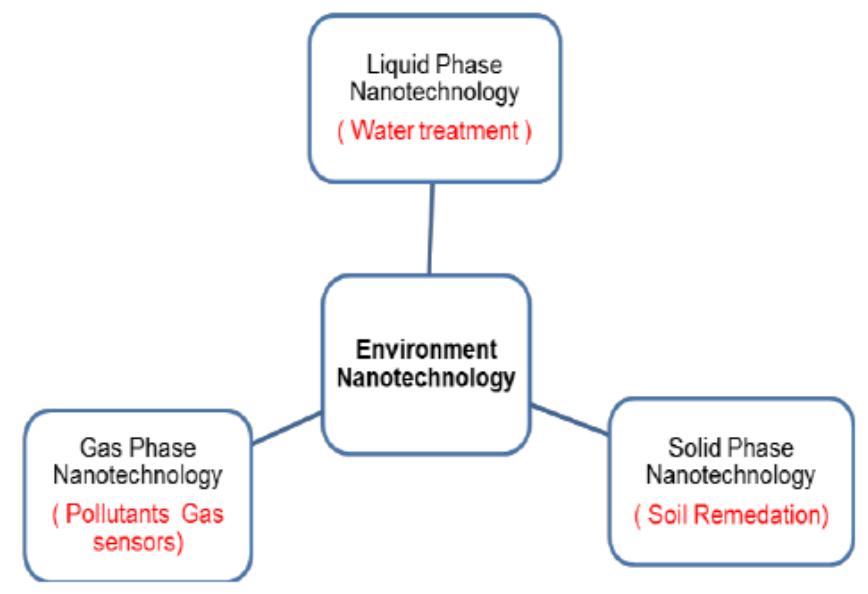

Figure 2. Nanotechnology application in the three phases of environment

(Source: Singh and Naveen, 2014) 


\section{Macrothink}

Environmental Management and Sustainable Development

ISSN 2164-7682

2017, Vol. 6, No. 2

Table 2. Nanotechnological applications in different environmental areas (Source: Mansoori et al., 2008)

\begin{tabular}{|c|c|c|c|c|}
\hline Type of nanoparticle & $\begin{array}{l}\text { Type of } \\
\text { treatment }\end{array}$ & Removal target & advantage & Disadrantage \\
\hline $\begin{array}{l}\text { Nanoparticles based } \\
\mathrm{TiO}_{2}\end{array}$ & $\begin{array}{c}\text { Photocatalyst } \\
\text { oxidation }\end{array}$ & Organic pollutants & $\begin{array}{l}\text { Non toxicity, Water insolubility under most } \\
\text { conditions, photo-stability }\end{array}$ & $\begin{array}{l}\text { High operation cost, Hard to } \\
\text { recovery, sludge generation }\end{array}$ \\
\hline $\begin{array}{l}\text { Nanoparticles based } \\
\text { iron }\end{array}$ & $\begin{array}{l}\text { Reduction, } \\
\text { adsorption }\end{array}$ & $\begin{array}{l}\text { Heavy metals, anions, } \\
\text { organic pollutants } \\
\text { (dechlorination) }\end{array}$ & $\begin{array}{l}\text { In situ remediation, soil \& water treatment, } \\
\text { Low cost, safe to handle }\end{array}$ & $\begin{array}{l}\text { Hard to recovery, sludge } \\
\text { generation, cost for sludge } \\
\text { disposal, Health risk }\end{array}$ \\
\hline $\begin{array}{l}\text { Nanoparticles based } \\
\text { Bimetallic }\end{array}$ & $\begin{array}{l}\text { Reduction, } \\
\text { adsorption }\end{array}$ & $\begin{array}{l}\text { Dechlorination, } \\
\text { denitrification }\end{array}$ & Higher reactivity than the iron nanoparticle & $\begin{array}{l}\text { Hard to recovery, sludge } \\
\text { generation, }\end{array}$ \\
\hline Nanoclay & Adsorption & $\begin{array}{l}\text { Heavy metals, organic } \\
\text { pollutants }\end{array}$ & $\begin{array}{l}\text { Low cost, Unique structures, Long-term } \\
\text { stability, reuse, High sorption capacity, Easy } \\
\text { recovery, large surface and pore volume }\end{array}$ & sludge generation \\
\hline Nanotube \& fullerene & Adsorption & $\begin{array}{l}\text { Heavy metals, anions, } \\
\text { organic pollutants }\end{array}$ & $\begin{array}{l}\text { Treatment of pollution from air \& water, } \\
\text { exceptional mechanical properties, unique } \\
\text { electrical properties, Highly chemical stability }\end{array}$ & $\begin{array}{l}\text { High capital cost, low adsorption } \\
\text { capacity, Hard to recovery, } \\
\text { sludge generation, Health risk }\end{array}$ \\
\hline Dendrimers & Encapsulation & $\begin{array}{l}\text { Heavy metals, organic } \\
\text { pollutants }\end{array}$ & $\begin{array}{l}\text { Simple separation, renewable, large binding } \\
\text { capacity, cost-effective, no sludge generation, } \\
\text { reduce pollutant to the level of a few ppb, } \\
\text { Treatment of pollution from soil \& water }\end{array}$ & Costly \\
\hline Micelles & Adsorption & $\begin{array}{l}\text { Organic pollutants } \\
\text { from soil }\end{array}$ & $\begin{array}{l}\text { In situ treatment, high affinity for hydrophobic } \\
\text { organic pollutant }\end{array}$ & Costly \\
\hline Metal-sorbing vesicles & Adsorption & Heavy metals & $\begin{array}{l}\text { Re-lse, high selective uptake profile, high } \\
\text { metal affinity }\end{array}$ & \\
\hline Magnetite nanoparticles & Adsorption & $\begin{array}{l}\text { Heavy metals, organic } \\
\text { pollutants }\end{array}$ & Simple separation, no sludge generation & $\begin{array}{l}\text { External magnetically field are } \\
\text { required for separation, Costly }\end{array}$ \\
\hline $\begin{array}{l}\text { Nanofilitration \& } \\
\text { nanosieve membranes }\end{array}$ & Nanofiltration & $\begin{array}{l}\text { Organic and inorganic } \\
\text { compound }\end{array}$ & Low pressure than $\mathrm{R} 0$ & $\begin{array}{l}\text { Costly, prone to membrane } \\
\text { fouling }\end{array}$ \\
\hline
\end{tabular}

\section{Nanotechnology and Air Pollution Control}

Air contamination is one of the world's most critical issues, and its definition is based on the changement in the natural atmospheric composition that is provoked by introducing different pollutants sources (chemical, biological or physical) resulting from human activity or industrial processes, such as carbon monoxide (CO), chlorofluorocarbons (CFC), heavy metals (As, $\mathrm{Cr}, \mathrm{Pb}, \mathrm{Cd}, \mathrm{Hg}$ ), hydrocarbons, nitrogen oxides, organic chemicals (VOCs, and dioxins), $\mathrm{SO}_{2}$, sand particles and biological substances (Fig.3) (Daly and Zannetti, 2007; Yu et al., 2009; Araújo et al., 2014; Ngo and Van de Voorde , 2014).

Ecosystem (e.g., vegetation and living organisms) as well as the human health is affected by poor air quality causing different types of fatal diseases, for example, cancer, respiratory, and cardiovascular diseases. The World Health Organization (WHO) in 2014 declared that air contamination caused the death of approximately 7 million individuals exposed in one year (2012). The effect of pollutants on mortality is schematically given in Figure 4 (Ngo and Van de Voorde , 2014). 


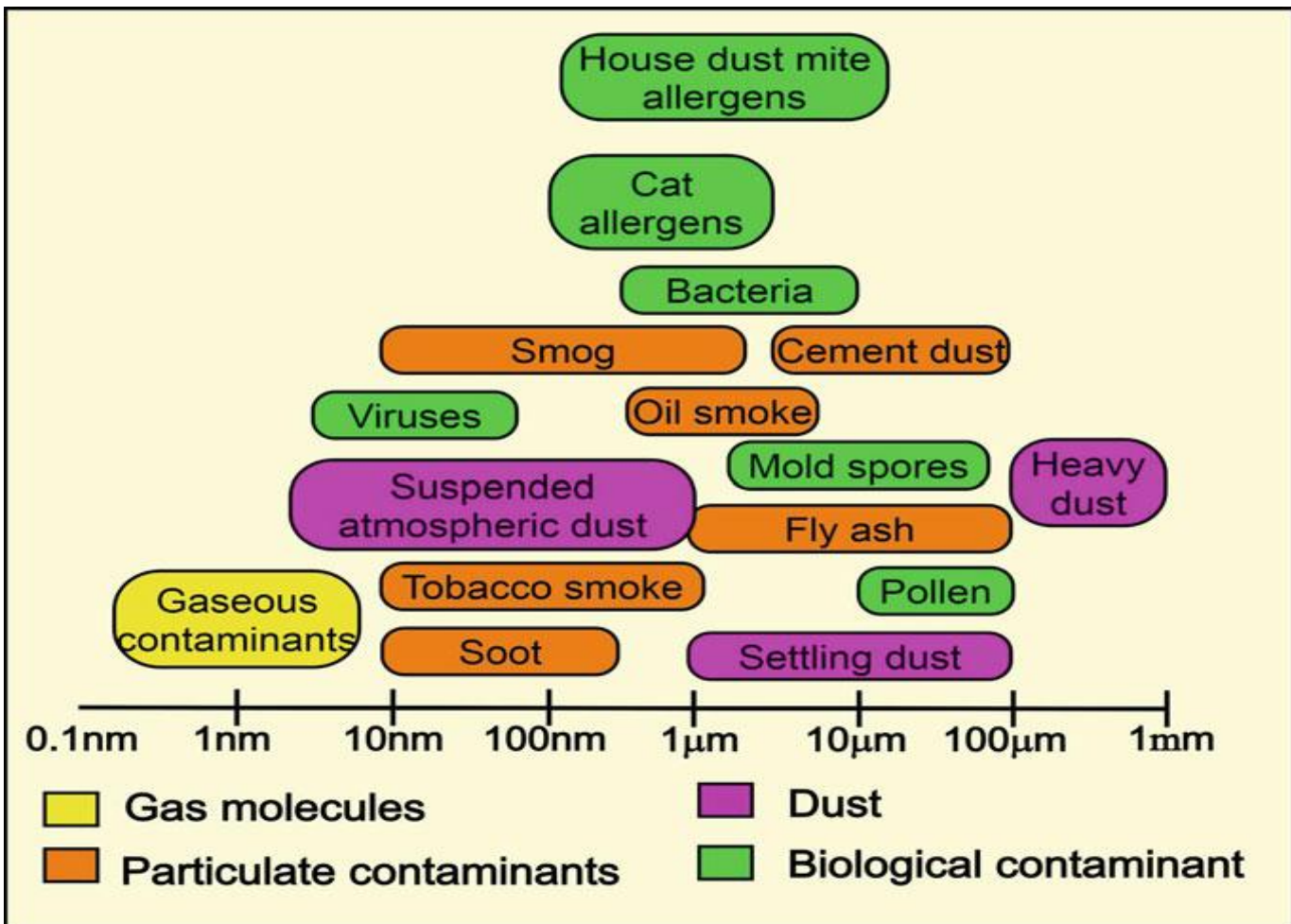

Figure 3. Different types of air contaminants

(Source: Ngo and Van de Voorde , 2014)

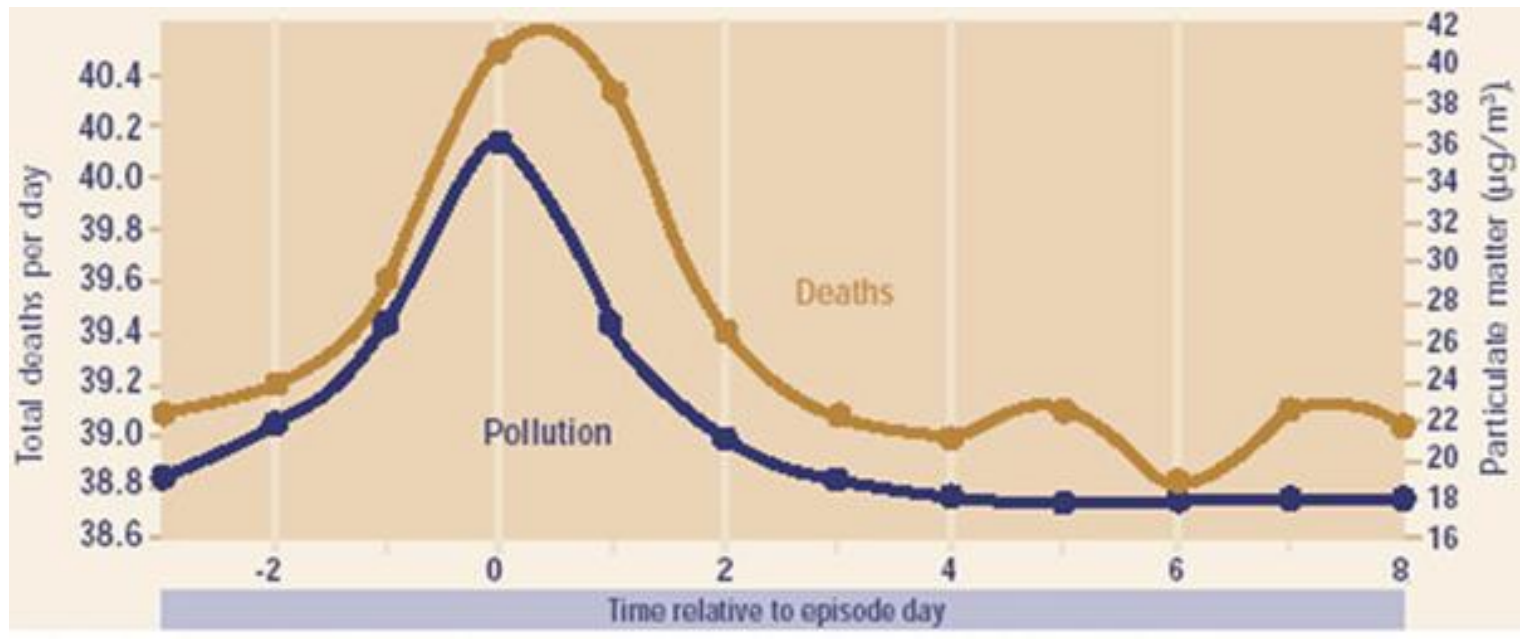

Figure 4. Effect of air pollution on mortality, 1986-94, Toronto, Canada

(Source: Ngo and Van de Voorde, 2014)

There is a requirement for innovations that are able to detect, perceive and treat such little concentrations of contaminants in air. In this, nanotechnologies offer various possibilities to control air pollution.

What would nanotechnologies be able to do? Nanotechnologies have the ability to produce innovative materials with unique properties that can be used in different environmental fields. 
(Falahi and Abbasi, 2013; Chirag, 2015; Ngo and Van de Voorde , 2014). Nanomaterials with small size and high surface/volume ratio have extremely significant monitoring character. These properties permit the improvement of highly accurate and sensitive nano-sensors devices. Nanomaterials can be designed to effectively react with a contaminant and degrade it into non toxic products. In addition to the detection and treatment of the contaminated area by applying nanotechnological processes in air pollution control, they can also apply to reduce the pollution in the future by replacing the toxic materials used with other safety materials. Another important application is the coatings technology that are nanostructured such that they have resistance of pollutants and possess self-cleaning features.

\subsection{Strategies of Nanotechnology to Control Air Pollution Problems}

Nanotechnology presents a number of potential environmental benefits in air pollution control. This could be mainly divided into three categories; remediation and treatment, detection and sensing, and pollution prevention (Sofian et al., 2012; Yadav et al., 2017).

\subsubsection{Treatment and Remediation}

There are three major ways in which nanotechnology is being used to treat and reduce the different air pollutants; adsorption by nano-absorptive materials, degradation by nanocatalysis, and filteration/separation by nanofilters.

Adsorption by nano-adsorptive materials

Nanoscience and nanotechnology supposed that many of the present problems including air quality can be solved or greatly ameliorated using the nanoscale adsorbents, called nanoadsorbents. Carbon nanostructures have extremely physical properties like average pore diameter, pore volume, and surface area making them significant for industrial application as nanoadsorbents with high selectivity, affinity, and capacity. Further, the highly reactive surface sites or structures bonds can also play an important role in the adsorption (Gupta and Saleh , 2013; Wang et al., 2013). Moreover, the addition of other functional groups with oxygen can also provide new active sites for adsorption (Wang et al., 2013). In this context, Figure 5 provides examples of diferent carbon nanostructures: fullerene (0D), carbon nanotubes (1D), graphene (2D), graphite (3D) (Bergmann and Machado, 2015).

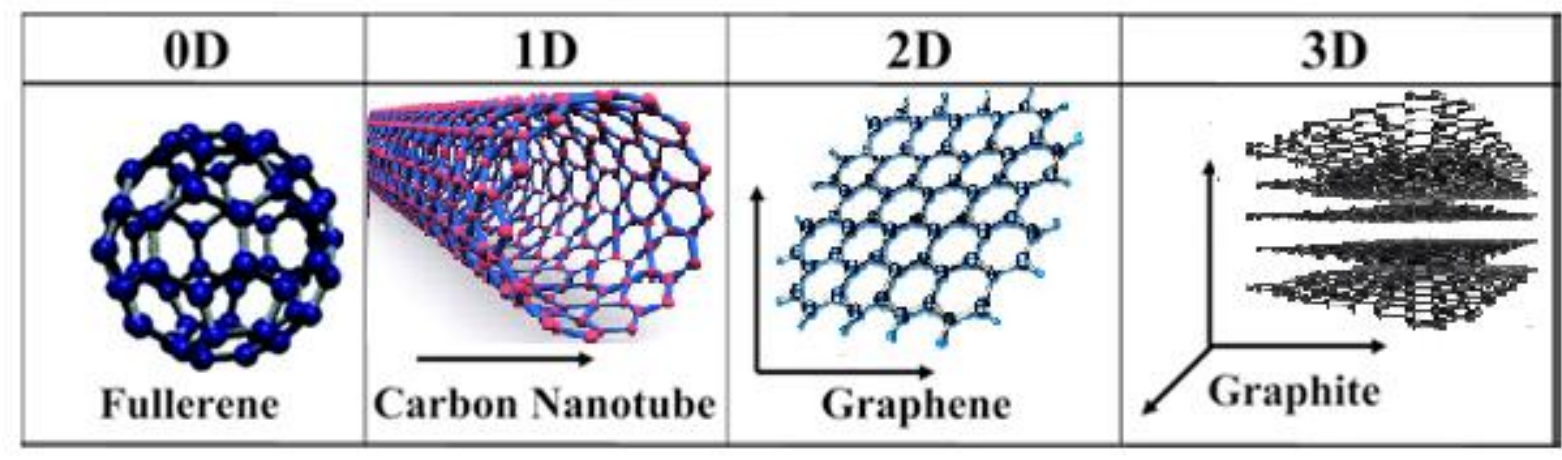

Figure 5. Examples for 0D, 1D, 2D, and 3D carbon nanostructures

(Source: Bergmann and Machado, 2015) 


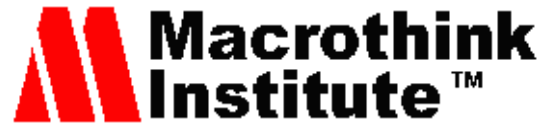

The global warming is considered now the principal outdoor air problem that causes changing in land, water sources and climate everywhere throughout the world. This is mainly due to Greenhouse gases (GHGs) (IPCC, 2014). The later includes $\mathrm{CO}_{2}, \mathrm{CH}_{4}, \mathrm{~N}_{2} \mathrm{O}$, and fluorinated gases. Most of the greenhouse gasses have permenant negative effect on atmosphere because of their capability to remain in the climate for many years. Air contaminants can be remediated and treated by various methods using nanomaterials as adsorbents (Gupta and Saleh , 2013; Wang et al., 2013; Bergmann and Machado, 2015).The creation of the carbon nanomaterials as well as methods to remove high quantities of gas pollutants has greatly investigated in the research field (Terrones et al., 2010; Wang et al., 2013).The properties of nanoadsorbents structure permit a great interaction with organic compounds via noncovalent forces such as hydrogen bonding, electrostatic forces, $\pi-\pi$ and hydrophobic interactions, and van der Waals forces (Ren et al., 2011). Furthermore, carbon nanotubes (CNTs) structure allows the combination of one or more surface functional groups $(\mathrm{OH}, \mathrm{COOH}, \mathrm{C}=\mathrm{O})$, which may increase the selectivity and the stability and influences the maximum adsorption capacity of the resulting system (Gupta and Saleh , 2013). CNTs, in particular, hold massive potential for applications because of their unique properties, such as high electrical and thermal conductivities, high strength, high hardness, and specific adsorption capacity (Wang et al., 2014).CNTs have cylindrical pores and adsorbent molecules interact with their carbon atoms on the surrounding walls. This interaction between molecules and solid surface depends on the pore size and geometry of pores. In addition, CNTs are more highly graphitic than the activated carbons. Thus, they have an adsorption capacity higher than activated carbons, which have slit or wedged pore shape (Ren et al., 2013). CNTs have 1D systems which result from graphene sheets (one or more) rolled up in a concentric form and exist in two forms as single walled carbon nanotubes (SWCNTs) and multi-walled carbon nanotubes (MWCNTs) (Fig. 6) (Zhao and Stoddart, 2009). Table 3 represents treatment techniques and conditions used by different researchers to eliminate and monitor the emission of the greenhouse gases and other air pollutants by differents nanoadsorptive materials.
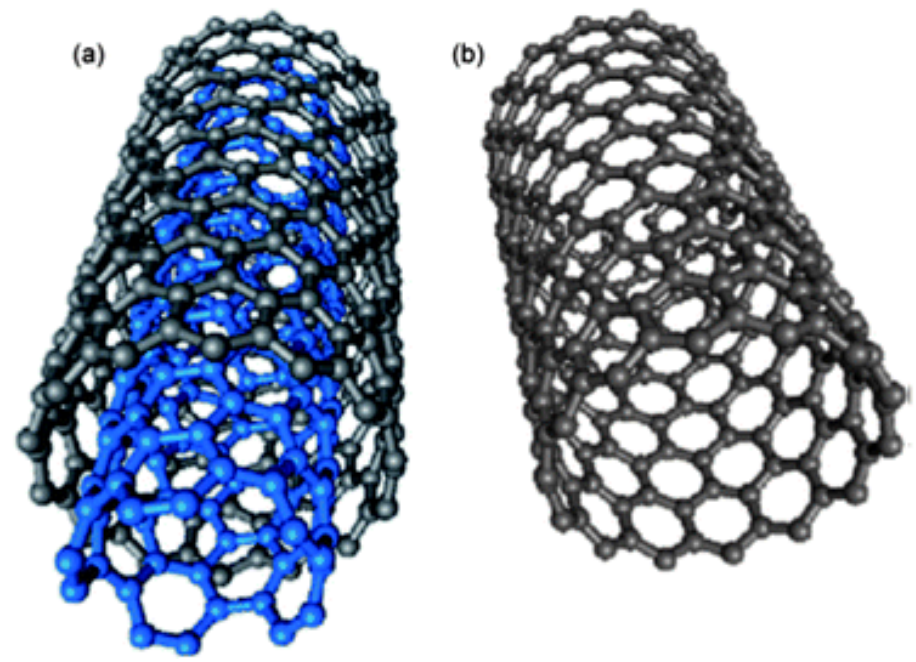

Figure 6. Structure representations of (a) MWCNT and (b) SWCNT

(Source: Zhao and Stoddart, 2009) 
Table 3. Treatment of greenhouse gases and other air pollutants by nanoadsorptive structures

\begin{tabular}{|c|c|c|c|c|}
\hline $\begin{array}{l}\text { Nanoadsorptive } \\
\text { materials }\end{array}$ & $\begin{array}{c}\text { Types of } \\
\text { nanoparticles }\end{array}$ & $\begin{array}{c}\text { Target } \\
\text { pollutant } \\
\text { gases } \\
\end{array}$ & Removal mechanism & References \\
\hline \multirow[t]{5}{*}{$\begin{array}{l}\text { Carbon } \\
\text { nanotubes } \\
\text { (CNTs) }\end{array}$} & $\begin{array}{l}\text { (SWNTs and } \\
\text { MWNTs) }\end{array}$ & $\begin{array}{l}\mathrm{NO} x \\
\text { (mixture of } \\
\mathrm{NO} \text { and } \mathrm{NO}_{2} \text { ) }\end{array}$ & $\begin{array}{l}\mathrm{NO} \text { and } \mathrm{O}_{2} \text { pass through } \mathrm{CNTs} \\
\text { and } \mathrm{NO} \text { is oxidized to } \mathrm{NO}_{2} \\
\text { and then adsorbed on the } \\
\text { surface of nitrate species. }\end{array}$ & $\begin{array}{l}\text { (Long and Yang , } \\
\text { 2001; Zhang et al., } \\
\text { 2012) }\end{array}$ \\
\hline & $\begin{array}{l}\text { (CNTs-APTS), } \\
\text { Modified CNTs } \\
\text { using } \\
\text { 3aminopropyltrietho } \\
\text { xysilane (APTS). }\end{array}$ & $\mathrm{CO}_{2}$ & $\begin{array}{l}\text { Surface of CNTs with } \\
\text { abundant amine groups that } \\
\text { provide numerous chemical } \\
\text { sites for } \mathrm{CO}_{2} \text { adsorption which } \\
\text { makes } \mathrm{CNT}_{\text {s adsorb more } \mathrm{CO}_{2}} \\
\text { gases at low temperature range } \\
\left(20-100^{\circ} \mathrm{C}\right) \text {. }\end{array}$ & (Su et al.,2009) \\
\hline & SWNTs/NaClO & $\begin{array}{l}\text { Isopropyl } \\
\text { vapor }\end{array}$ & $\begin{array}{l}\text { Physical adsorption by van } \\
\text { derWaals forces and chemical } \\
\text { adsorption onto adsorbent } \\
\text { surface functional groups. }\end{array}$ & (Hsu and Lu, 2007) \\
\hline & $\begin{array}{l}\text { CNTs deposited on } \\
\text { quartz filters }\end{array}$ & VOCs & $\begin{array}{l}\text { It carried out by } \pi-\pi \\
\text { interactions. }\end{array}$ & (Amade et al., 2014) \\
\hline & $\begin{array}{l}\text { Si-doped and } \\
\text { Boron-doped } \\
\text { SWCNTs }\end{array}$ & $\begin{array}{l}\mathrm{CO} \text { and } \\
\mathrm{CH}_{3} \mathrm{OH} \\
\text { gases }\end{array}$ & $\begin{array}{l}\text { Physisorption or } \\
\text { chemisorption, the electronic } \\
\text { properties of SWCNT } \\
\text { improves significantly the gas } \\
\text { adsorption. }\end{array}$ & (Azama et al., 2017) \\
\hline \multirow[t]{2}{*}{ Fullerene } & fullerene $\mathrm{B}_{40}$ & $\mathrm{CO}_{2}$ & $\begin{array}{l}\text { high adsorption capacity for } \\
\mathrm{CO}_{2} \text { by strong chemisorptions. }\end{array}$ & (Dong et al., 2015) \\
\hline & $\begin{array}{l}\text { fullerene-like boron } \\
\text { nitride nanocage }\end{array}$ & $\mathrm{N}_{2} \mathrm{O}$ & $\begin{array}{l}\text { Adsorption and decomposition } \\
\text { of } \mathrm{N}_{2} \mathrm{O} \text {. }\end{array}$ & (Esrafili , 2017) \\
\hline Graphene & $\begin{array}{l}\text { Graphene oxide } \\
\text { (GO)/nanocomposits }\end{array}$ & $\begin{array}{l}\mathrm{CO}_{2}, \mathrm{NH}_{3} \\
\mathrm{SO}_{2}, \mathrm{H}_{2} \mathrm{~S} \\
\text { and } \mathrm{N}_{2}\end{array}$ & $\begin{array}{l}\text { Functional groups on GO are } \\
\text { responsible for adsorption of } \\
\text { gases, synergetic effect } \\
\text { between the metal centers and } \\
\text { GO surface promote the gases } \\
\text { adsorption. }\end{array}$ & $\begin{array}{l}\text { (Petit and Bandosz, } \\
\text { 2009; Seredych and } \\
\text { Bandosz , 2012; Wu } \\
\text { et al., 2013) }\end{array}$ \\
\hline
\end{tabular}

a. Degradation by Nanocatalysis

Indoor air pollution has received significant attention since the early 1990s because people generally spend more than $80 \%$ of their time indoors and the indoor risk from inhalation of pollutants is higher than the outdoors one. Among the indoor air pollutants are VOCs which are considered as harmful gases to human health (Salthammer, 2016). Consequently, healthy indoor air quality in our environment requires special attention. Air pollution can be 
controlled using nanotechnology in several ways. One is through the use of semiconducting materials photocatalytic remediation, the exposure of these materials to a light with energy equal to that of its band gap led to the formation of electron-hole pair. The active surface is considered the most important catalyst properties where the reaction occurs. As the catalyst's size decreased, its active surface increased leading to the increase in the reaction efficiency (Özkar,2009). Nanotechnology can improve the nanoparticle size and molecular structure/distribution for the development of new nano-catalysts with increased surface area. Nanocatalysts are promising in ameliorating air quality and for reducing air pollutants to a lesser extent. Nanocatalytic system allows rapid and selective chemical transformations with excellent product yield coupled with the facility of catalyst recovery as compared with other conventional catalysts.

Figure 7 represents scheme of comperative efficiency of homogeneous, heterogeneous and nanocatalysis (Singh and Tandon ,2014).

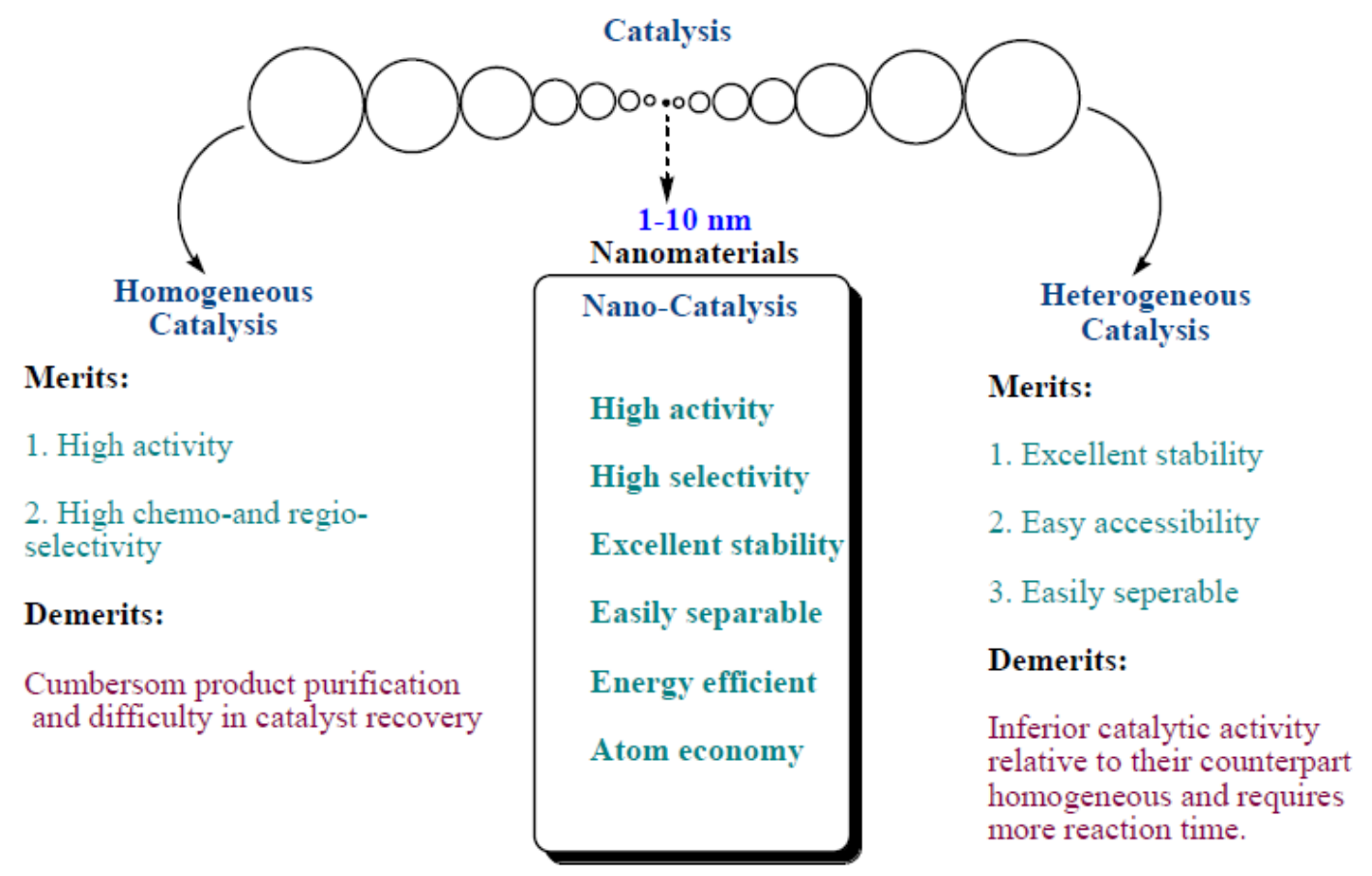

Figure 7. Comperative efficiency of homogeneous, heterogeneous and nanocatalysis

(Source: Singh and Tandon, 2014)

The photocatalytic properties of titanium dioxide nanoparticles $\left(\mathrm{TiO}_{2}\right)$ are being exploited to manufacture "self cleaning" coatings that are capable to depollution atmospheric contaminants such as nitrogen oxides, VOCs and other pollutants into less toxic species (Shen et al., 2015).

In addition, $\mathrm{TiO}_{2}$ nanoparticles are used as antibacterial. The nanoparticles antibacterial activity was inversely proportional to particle size and relates to their capability to produce active carriers giving rise to active surface species. Generally, the photocatalytic reduction reaction can be divided into 4 main steps (Fig. 8): (1) pollutant adsorption, (2) electron-hole 
pair generation by absorbing sufficient incident photon energy, (3) electron-hole pair separation and their migration to the photocatalyst surface and (4) pollutant reduction (Low et al., 2017).

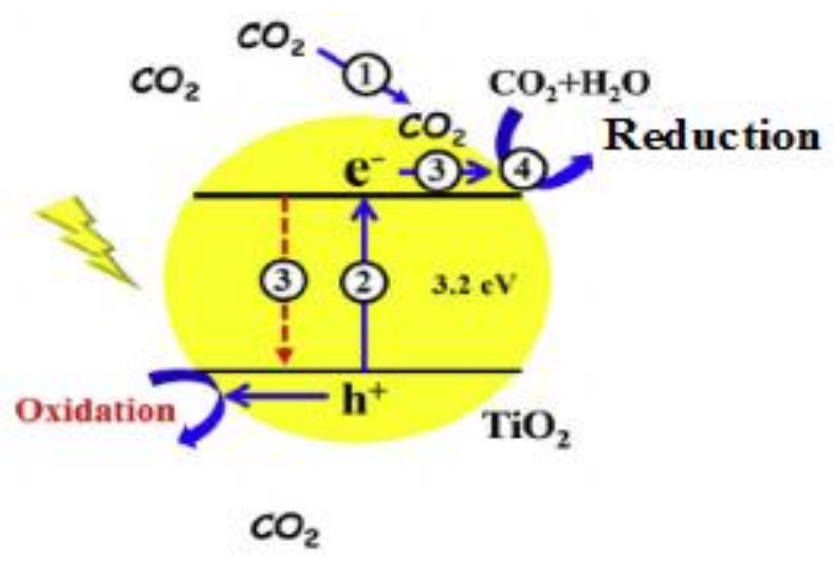

Figure 8. Schematic illustration of the adsorption and oxidation of $\mathrm{CO}$ on $\mathrm{TiO}_{2}$

(Source: Low et al., 2017)

Currently, carbon nanostructures such as CNTs and graphene nanosheets have been widely used for increasing the photocatalytic efficiency of $\mathrm{TiO}_{2}$ where, in composite of $\mathrm{TiO}_{2}-\mathrm{CNTs}$ the electrons can be easily transfered through the CNTs and retard the electron-hole recombination (Low et al., 2017). The conduction band of CNTs lies at a more positive level compared to that of $\mathrm{TiO}_{2}$, hence the electrons can be moved from $\mathrm{TiO}_{2}$ to CNTs (Fig. 9).

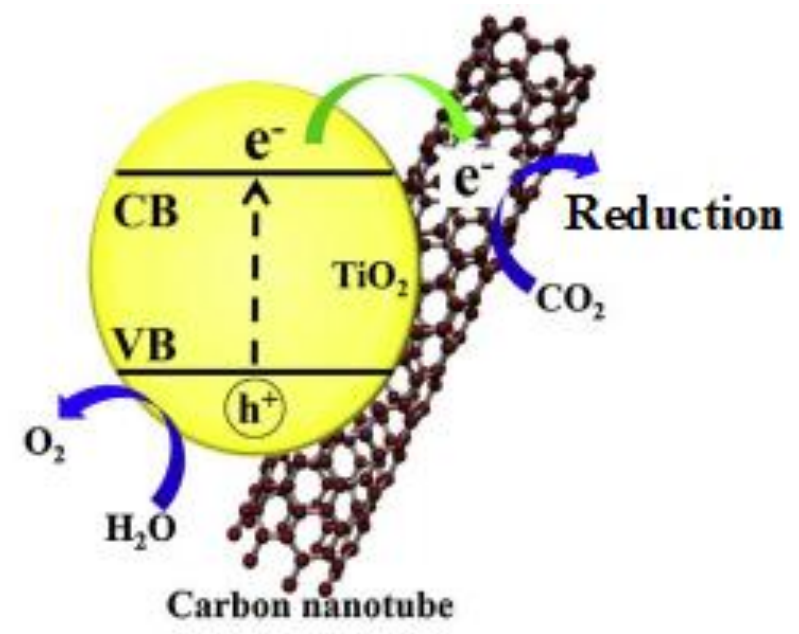

Figure 9. Schematic illustration shows the overall charge transfer mechanism in $\mathrm{TiO}_{2} / \mathrm{CNT}$ nanocatalyst (Source: Low et al., 2017)

New synthesis methods for effective metal oxide nanocatalysts will help to reduce and may solve the air pollution problems. A nanofiber of silver, iron, gold and manganese oxide are some of the recently used nanoscale metals and metal oxides reported by the researchers that can be used in environmental control to remove several volatile organic compounds from industrial smokestacks. Nanogold based catalysts have extremely important treating effect on 


\section{Macrothink}

various contamination control studies to convert the toxic air pollutants (Singh and Tandon ,2014).

For example, it can eliminate carbon monoxide from indoor air at room temperature. Another example, Au-Pt co-catalyst was found to be 100 times more active than that made of a conventional material for trichloroethylene (TCE) decomposition. As a concept, $\mathrm{ZnO}$ photocatalyst is currently being developed and is expected to have two functions to detect and reduce contaminants (Yadav et al., 2017). Table 4 presents an overview of the nano-technologies identified for reduction of air pollution and/or improvement of indoor or outdoor air quality including nanocatalysts involved, functionality, application areas and stage of development (Christensen et al., 2015).

Table 4. Nanocatalysts applications for air pollution reduction and air quality (Source: Christensen et al., 2015)

\begin{tabular}{|c|c|c|c|}
\hline Application/product & $\begin{array}{l}\text { Involved } \\
\text { "nano" } \\
\text { (material, } \\
\text { surface etc.) }\end{array}$ & $\begin{array}{l}\text { Why is "nano" } \\
\text { applied? }\end{array}$ & Development stage \\
\hline $\begin{array}{l}\text { Air pollution reduction by } \\
\text { nano-treated surfaces } \\
\text { (e.g. coated walls, roofs or } \\
\text { pavement slabs, treated } \\
\text { road surfaces, film } \\
\text { materials with nano-TiO } 2 \\
\text { embedded etc.) }\end{array}$ & $\begin{array}{l}\mathrm{TiO}_{2} \text {, at least } \\
\text { commercially }\end{array}$ & $\begin{array}{l}\text { Photocatalyst for } \\
\text { NOx and VOC } \\
\text { removal }\end{array}$ & $\begin{array}{l}\text { Commercially available, } \\
\text { but not widespread }\end{array}$ \\
\hline $\begin{array}{l}\text { Catalytic industrial } \\
\text { emission reduction } \\
\text { (e.g. deNOx converter } \\
\text { systems for power plants } \\
\text { or incineration plants }\end{array}$ & $\begin{array}{l}\text { Vanadium (V) } \\
\text { (above all) } \\
\text { Molybdenum }\end{array}$ & $\begin{array}{l}\text { Catalyst for } \mathrm{NO}_{\mathrm{x}} \\
\text { removal } \\
\text { Removal of sulfur }\end{array}$ & $\begin{array}{l}\text { Widely used for } \mathrm{NO}_{\mathrm{x}} \\
\text { reduction, especially at } \\
\text { coal-fired power plants. } \\
\text { Used at e.g, refineries }\end{array}$ \\
\hline $\begin{array}{l}\text { Catalytic car exhaust } \\
\text { emission reduction } \\
\text { (catalysts for diesel cars) }\end{array}$ & $\begin{array}{l}\text { Platinum (Pt), } \\
\text { palladium (Pd), } \\
\text { rhodium (Rh) }\end{array}$ & $\begin{array}{l}\text { Catalyst primarily } \\
\text { for } \mathrm{NO}_{\mathrm{x}} \text { removal }\end{array}$ & $\begin{array}{l}\text { Widely used in diesel- } \\
\text { fueled automobiles }\end{array}$ \\
\hline $\begin{array}{l}\text { Indoor air purification by } \\
\text { nano-treated surfaces } \\
\text { (treated/coated indoor } \\
\text { walls, floors, desk tops) }\end{array}$ & $\mathrm{TiO}_{2}$ & $\begin{array}{l}\text { Catalyst primarily } \\
\text { for removal of VOCs } \\
\text { and } \\
\text { bacteria/viruses }\end{array}$ & $\begin{array}{l}\text { Barely on the market as } \\
\text { yet }\end{array}$ \\
\hline $\begin{array}{l}\text { Indoor air purification by } \\
\text { photocatalytic reactors } \\
\text { (domestic stand-alone } \\
\text { electrical devices) }\end{array}$ & $\mathrm{TiO}_{2}$ & $\begin{array}{l}\text { Catalyst primarily } \\
\text { for VOC removal }\end{array}$ & $\begin{array}{l}\text { A few commercial } \\
\text { products exist }\end{array}$ \\
\hline $\begin{array}{l}\text { Indoor air purification by } \\
\text { nano-treated filters } \\
\text { (filters to be incorporated } \\
\text { in centralised ventilation } \\
\text { systems) }\end{array}$ & Silver (Ag) & $\begin{array}{l}\text { Anti-bacterial } \\
\text { biocide }\end{array}$ & $\begin{array}{l}\text { A few commercial } \\
\text { products exist }\end{array}$ \\
\hline
\end{tabular}




\section{Macrothink}

Today, the catalysts application under the solar radiation is considered as one of the most important targets in the photocatalytic field. Nanotechnology can lead to produce new nanocatalysts applied in visible light irradiation for air pollution control. For example, Bismuth oxybromide (BiOBr) nanoplate microspheres catalyst (Fig.10 a,b) was used to remove NO in indoor air under visible light $(\lambda>420 \mathrm{~nm})$ at $400 \mathrm{ppb}$ level, which is typical concentration for indoor air quality (Fig.10C) (Ai et al., 2015).
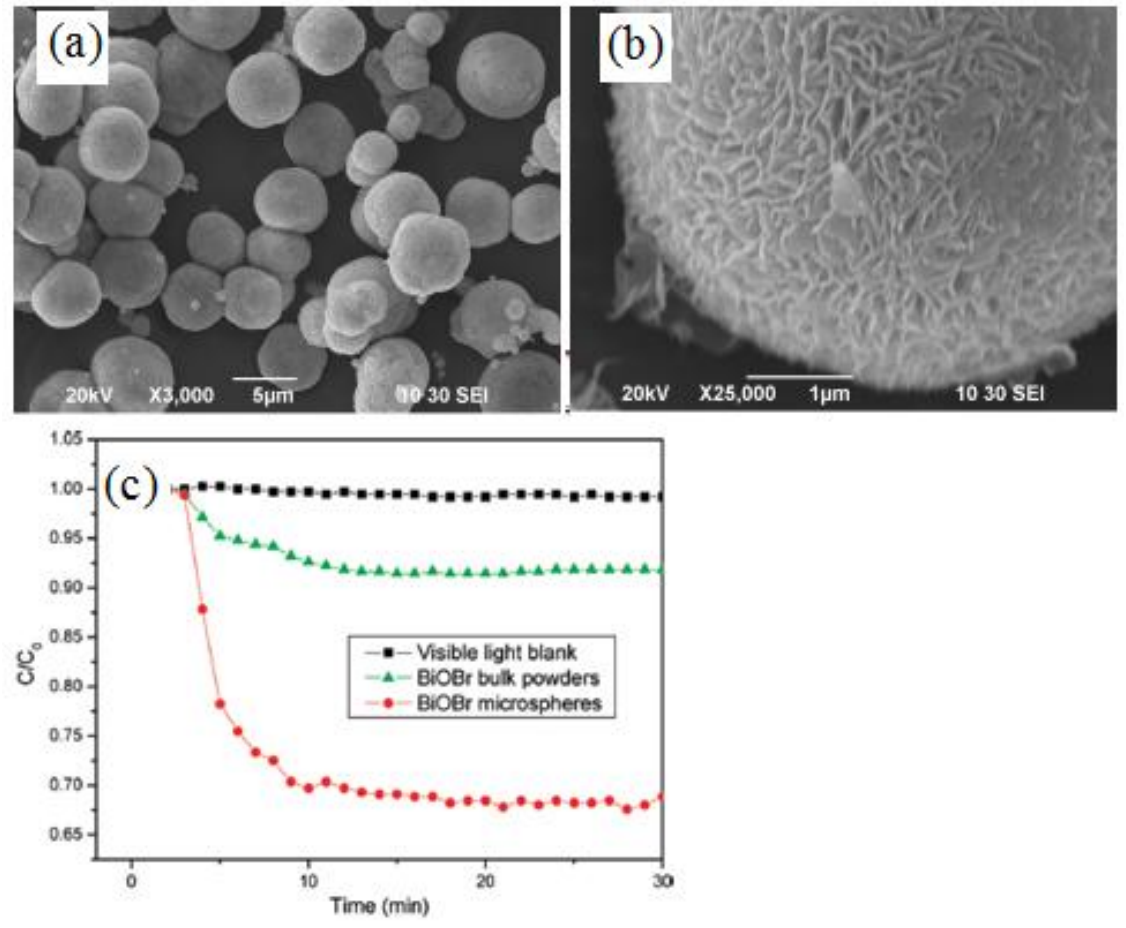

Figure 10. SEM images at low magnification (a), high magnification (b) of the $\mathrm{BiOBr}$ nanocatalyst and the decrease in $\mathrm{NO}$ concentration by $\mathrm{BiOBr}$ nanocatalyst under UV-visible light irradiation(c) (Source: Ai et al., 2015)

b. Filtration/separation by Nanofilters

Another approach for air pollution control is nanostructured membranes that have pores small enough to separate different pollutants from exhaust. Research focuses on the improvement and optimization of nano-structured membranes to capture several gas polluants. Nanofibre-coated filter media are used for air filtration (e.g. dust removal) at industrial plants and for filtration of the inlet air for gas turbines ) (Muralikrishnan et al., 2014). In particulate, filteration by nano-structured membranes is suitable for several VOCs vapors (Scholten et al., 2011).For example, formaldehyde (HCHO) imposes great challenges for its removal. Traditional photochemical techniques utilizing photocatalysts are not appropriate for the indoor HCHO removal due to the necessity of UV light illuminations and the danger of destructive ozone liberation (Miyawaki et al., 2012). Hence, the removal of formaldehyde has been improved through many techniques, for example, electrospun polyacrylonitrile (PAN)based carbon nanofiber (CNF) membrane with high microporosity and abundant nitrogen-containing functional groups as effective adsorption sites was produced (Lee et al., 


\section{Macrothink}

Environmental Management and Sustainable Development

ISSN 2164-7682

2017, Vol. 6, No. 2

2010). A reasonable quantity of formaldehyde even at a low concentration was adsorbed onto the PAN-activated carbon nanofiber (ACNF). An additional example in indoor air pollutants is bioaerosols (aerosols of biological origin such as viruses, bacteria, and fungi), they can rapidly grow and provoke several diseases, such as allergies and infections. Silver nanoparticles and copper nanoparticles filters are widely used in the air filtration technology as antimicrobial materials to remove bioaerosols through air conditional processes. In this, many studies have cited that silver nanoparticles could successfully eliminate bacterial bioaerosols (Lee et al., 2010). One of the most environmental challenges is the removing of particulate matter (PM) which causes serious harm to public health. Metal-organic frameworks (MOFs) are crystalline materials with high porosity, tunable pore size, and rich functionalities, holding the promise for contaminant capture (Zhang et al., 2016). Here, nanocrystals of four unique MOF structures are processed into nanofibrous filters. The MOFilters show high removal efficiencies for PM2.5 and PM10 (Fig.11). These MOFilters can also be effective and selective to adsorb toxic gases such as $\mathrm{SO}_{2}$ when exposed in a stream of $\mathrm{SO}_{2} / \mathrm{N}_{2}$ mixture.

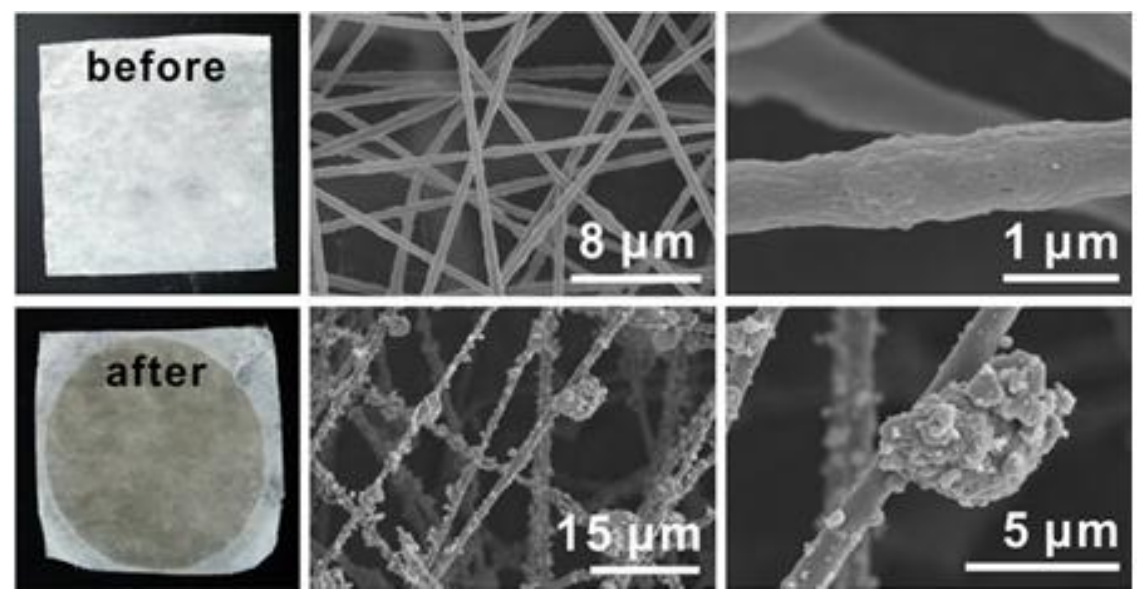

Figure 11. Photos and SEM images of the MOFilter before and after PM capture

(Source: Zhang et al., 2016)

\subsubsection{Nanotechnology for Air Pollution Prevention}

Prevention of air pollution refers to a reduction in pollution sources and other practices that utilize raw materials, energy, utilities and other resources effectively in order to reduce or eliminate waste generation. Nanotechnology offers many innovative strategies to reduce waste production in various processes such as improving manufacturing processes, reducing hazardous chemicals, reducing greenhouse gas emissions and reducing the use of synthetic plastics.

The application of nanotechnology is able to create an environmentally friendly substance or material, replacing widely used toxic materials. The advantage of this technology is the increased efficiency, reduced system costs and whole replacement, as well as reduced environmental impact. Examples of environmentally friendly materials that can be produced using nanotechnology are (Yadav et al., 2017): biodegradable plastics have specific 


\section{Macrothink}

structure for degradation, non-toxic-nanocrystalline composite materials to substitute the electrodes of lithium-graphite in rechargeable batteries, and new types of nanomaterials having better performance and less toxicity instead of traditional materials. As an example, carbon nanotubes can provide better functionality than the conventional cathode tubes that contain many toxic metals. Other example of environmentally friendly substance is self-cleaning glasses, for example, Activ ${ }^{\mathrm{TM}}$ Glass, market product from Pilkington (Yadav et al., 2017). The glass has an extraordinary covering made of $\mathrm{TiO}_{2}$ nanocrystals which, when exposed to sunlight, interacts in two pathways: the first one is the degradation of any organic pollutants deposited on the glass, The second way, under rain, water droplets form a sheet, then the pollutants on the surface are picked up by water and wash off the glass (Fig.12) (Yadav et al., 2017).
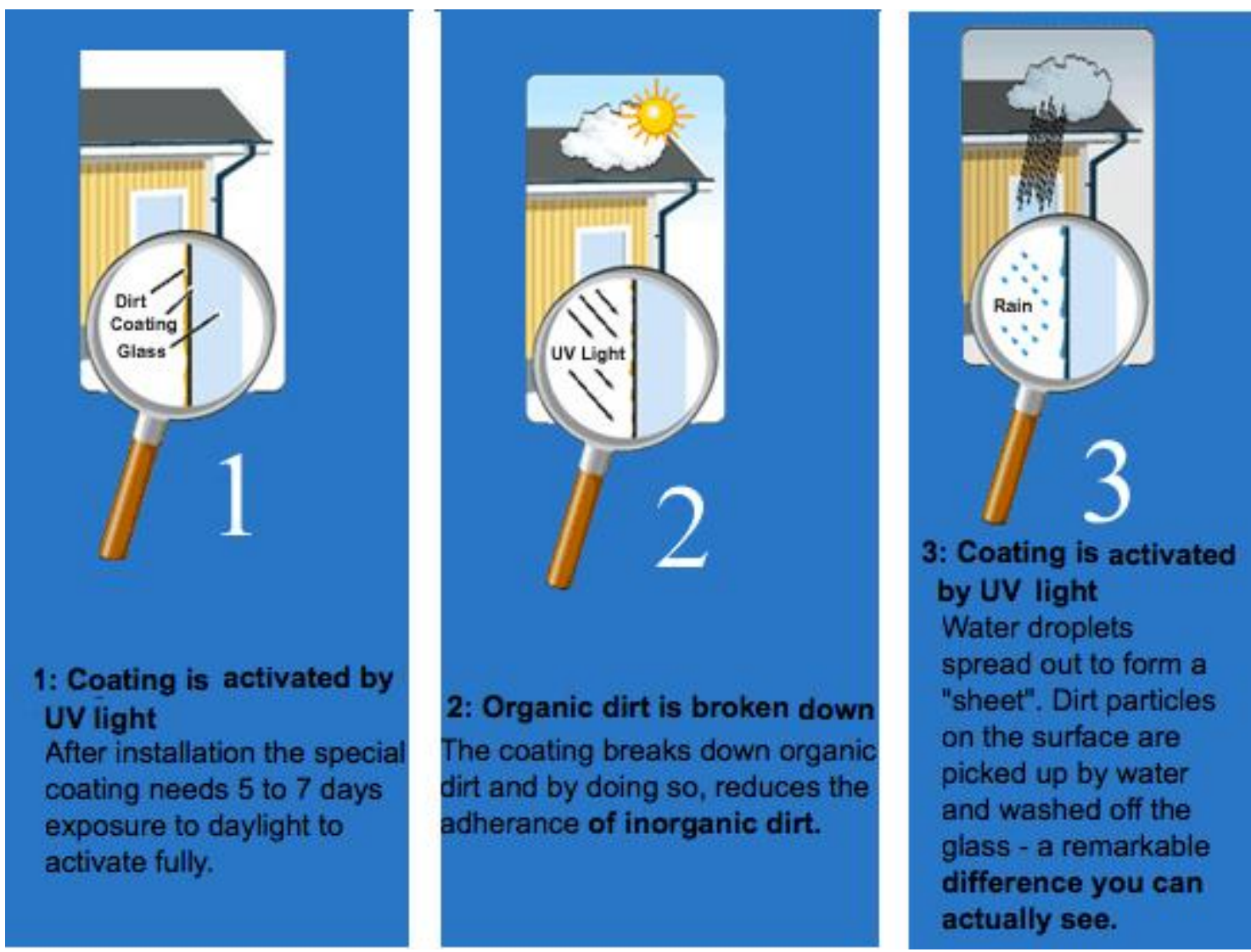

Figure 12. Explanation on how Pilkington Activ ${ }^{\mathrm{TM}}$ Self-cleaning Glass works as described by the manufacturer (http://www.pilkington.com) (Source: Yadav et al., 2017)

\subsubsection{Sensing and Detection}

Large increases in process control, ecosystem monitoring and environmental based decision can occur if the available contaminant detection technology is more sensitive and less expensive. Sensing and detecting the pollutants in air is an essential step in the control process. Conventional methods (Physical, chemical and biological) are used to detect the nature and the concentration of the pollutant present. Even though these attempts are highly accurate and specific, they need sampling and consecutive analysis in the laboratory. These 
methods require more time, a lot of expertise and furthermore are costly. As a result, these techniques are incapable of determining the exact composition and type of the pollutant under field conditions. At present, nanotechnology plays a significant role in sensing the pollutants by improving sensors more specific and sensible for air monitoring. Nanoensors are presently being utilized for the detection of several toxic compounds at ppm and ppb levels in different environmental systems (Zhou et al., 2015).Nanotechnology plays an important role in sensing via many ways (Zaporotskova et al., 2016) : at first, the nanoparticles are able to be coated with several chemical and biological ligands helping to improve the sensor specificity. Secondly, the surface/volume ratio of the nanoparticles allowed to vary the size and shape of the nanoparticles thus controlling the interaction with the pollutant molecule. Finally, the conductivity and sensitivity are improved via construction nanoparticles of different metals.New innovations have developed in the utilization of nanotechnology in environmental sensors, the main advantages of these sensors are; faster, high specifity, can detect the microorganisms (e.g. bacteria) at a lower concentration, rapid response and detection of numerous analytes in the same device (Bhawana and Fulekar, 2012; Kim et al., 2016). Nanotechnology will permit the production of very-small 'multiplex' sensors, thus leading to the decrease in the analysis cost and the number of devices used for the analysis.

Development in nanoelectronics will permit the creation of nanosensors fit for continuous detection. Carbon nanotube based sensor is one example of nanosensor used for sensing various gases like $\mathrm{NH}_{3}, \mathrm{NO}_{2}$ or $\mathrm{O}_{3}$ (Ye et al., 2015; Azama et al., 2017). During contacting with these gases, the nanotubes electrical resistance is markedly changed, then measured. Several examples of nanostructural materials and/or devices developed for detection a variety of pollution control is highlighted in Table 5.

Consequently, nanoparticles-based sensors can be a reasonable apparatus for quick recognition of air contaminants. Much advance in such manner has been made with the innovation of intelligent dust, made of an arrangement of light computerized nanosensors, which can stay in the environment for a considerable period of time. In addition to be smaller and accurate than others, these nanosensors are cost effective due to very limited power usage and effective performance.

Table 5. Pollution detection and sensing- nanostructural material (Source: Bhawana and Fulekar, 2012)

\begin{tabular}{|l|l|}
\hline Nanostrucure material & Function \\
\hline $\begin{array}{l}\text { Silver nanoparticle } \\
\text { array membranes }\end{array}$ & Water quality monitoring \\
\hline $\begin{array}{l}\text { Carbon nanotubes } \\
\text { (CNTs) }\end{array}$ & Electrochemical sensors \\
\hline $\begin{array}{l}\text { CNTs as a building } \\
\text { block }\end{array}$ & $\begin{array}{l}\text { Exposure to gases such as } \mathrm{NO}_{2}, \mathrm{NH}_{3} \text { or O, the electrical resistance } \\
\text { of CNTs changes dramatically, induced by charge transfer with } \\
\text { the gas molecules or due to physical adsorption }\end{array}$ \\
\hline CNTs with enzymes & $\begin{array}{l}\text { Establish a fast electron transfer from the active site of the } \\
\text { enzyme through the } \mathrm{CNT} \text { to an electrode, in many cases }\end{array}$ \\
\hline
\end{tabular}




\begin{tabular}{|c|c|}
\hline & enhancing the electrochemical activity of the biomolecules \\
\hline CNTs sensors & $\begin{array}{l}\text { Developed for glucose, ethanon, sulphide and sequence-specific } \\
\text { DNA analysis }\end{array}$ \\
\hline $\begin{array}{l}\text { Magnetic nanoparticles } \\
\text { coated with antibodies }\end{array}$ & Usful for the rapid detection of bacteria in complex matrices \\
\hline
\end{tabular}

\section{Future Promising of Nanotechnology for Turning Air Pollutants into Fuel}

For increasing the energy needs and limiting greenhouse gas emissions in the future, the power capacity requierements on a large scale will need to be provided from renewable sources. The conversion of carbon dioxide and water into fuels in a solar refinery represents a potential solution for decreasing greenhouse gas emissions. The two principal possibilities for $\mathrm{CO}_{2}$ conversion include (1) catalytic conversion using solar-derived hydrogen and (2) direct reduction of $\mathrm{CO}_{2}$ using $\mathrm{H}_{2} \mathrm{O}$ and solar energy (Fig. 13) (Herron et al., 2015). The advanced nanotechnologies are greatly related to solar-to-fuel conversion, that needs for an intensive research and development effort to bring such processes to be commercialized. The nanostructured materials can play a significant role in improving the reaction efficiency and the rate of $\mathrm{CO}_{2}$ reduction into fuel chemicals. Nanotechnology incorporated in this item by developing several novel carbon nanomaterials used for $\mathrm{CO}_{2}$ capturing and also nano-catalysts that are responsible for the catalytically conversion of $\mathrm{CO}_{2}$ and $\mathrm{H}_{2} \mathrm{O}$ to fuels (Raj et al., 2017). Hence, it reduces the carbon dioxide emissions from many industries, gives a significant solution for the Earth warming problems, and produces additional source of energy.

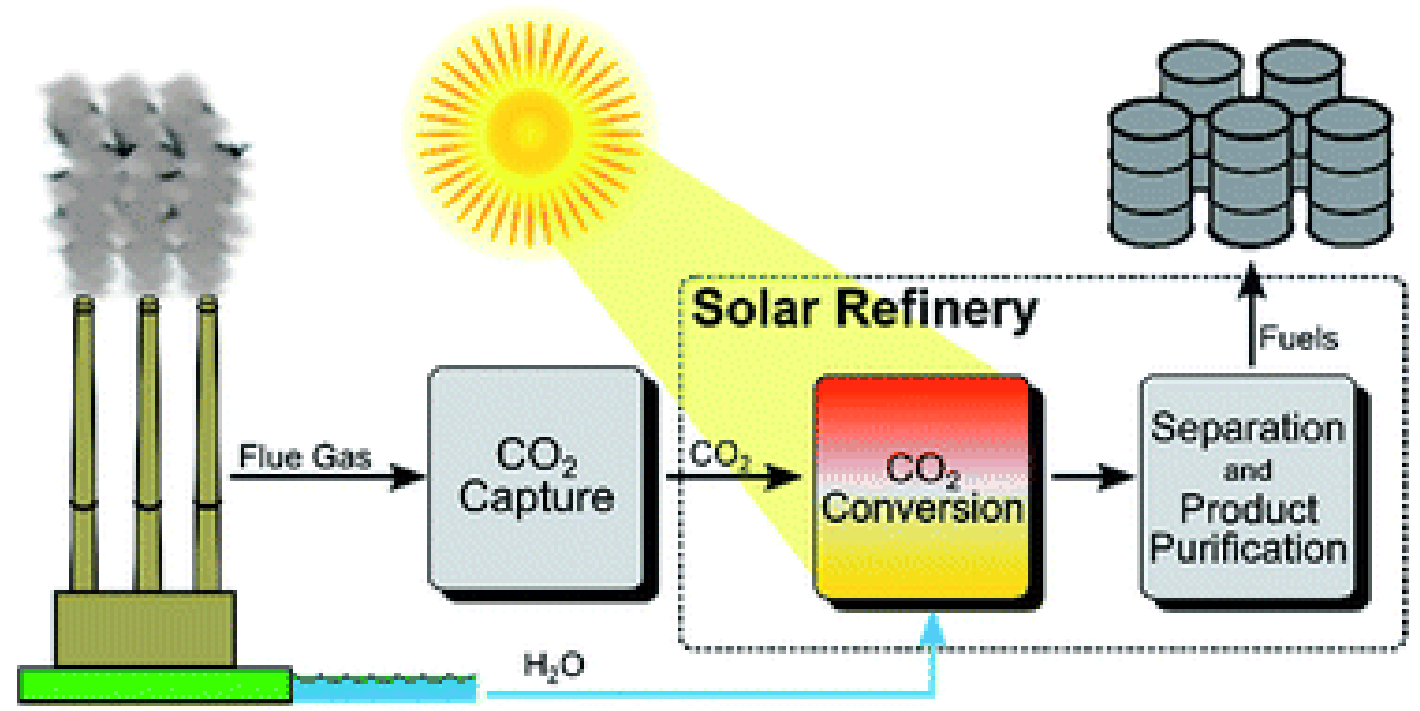

Figure 13. Conversion of carbon dioxide and water into fuels in a solar refinery

(Source: Herron et al., 2015)

\section{Regulation of Nanotechnology}

Keeping in mind the broad range of application of nanotechnologies summarized previously, there is no dought that the nanotechnologies will also form a set of risk. The use of nanoparticles in environmental remediation applications will lead to the release of air-borne 
particles into the environment. Estimating their risks in the environment requires an understanding of their mobility in the environment, bioavailability and distribution in food chain, may negatively affect ecosystem and health impacts. To ensure that nanoscale materials are manufactured and used in a manner that protects against human health and environmental risks, in 2009, EPA (Environmental Protection Agency) began work on a TSCA regulation (Toxic Substances Control Act) (EPA, 2017), that would be applicable to all nanoscale materials. It would have two components:

\section{a) Significant New Use Rule (SNUR)}

EPA has permitted limited manufacture of novel nanoscale materials through the use of approval orders or Significant New Use Rules (SNUR) under TSCA. Prior to manufacturing chemicals or introducing them into commerce, manufacturers of new chemical substances must provide more information to the Agency for review. EPA can take action to ensure that chemicals that may or will pose an unreasonable risk to human health or the environment are effectively controlled.

b) Information reporting rule

This rule requires companies that manufacture (including import) or process certain chemical substances already in commerce as nanoscale materials notify EPA of certain information including: specific chemical identity, production volume, methods of manufacture, processing, use, exposure and release information, available health and safety data. By collecting such data, EPA will finally be able to draw a clearer picture of the nanomaterials for commercial and scientific use.

\section{Conclusions}

The applications of nanomaterials in environmental fields are referred to as "environmental nanotechnology." Because nanoparticles have unique properties such as magnetic, optical, electrical and high structural properties, they have a considerable potential to substitute existing materials.

Nanotechnology is widly applied in monitoring and remediating existing different air and environmental pollutants and also preventing new pollution. Nanoparticles are used in applications in novel sensing technologies for pollutants detection at lower concentrations. The capability of nanoparticles to be coated with several ligands and control surface area/volume ratio by means of changing its shape permits to make a design of high selective, sensitive, and specific sensors. Nanoparticles can also incorporate in clean up air contaminants via adsorption, oxidation and filteration techniques. In adsorption removal technique, nanoparticles have the ability to adsorb maximum amount of air contaminants owing to its large surface area. In the oxidation treatment process, nanocatalysts catalyze the reactions in faster rate in comparison to bulk material, therefore, the consumed energy is reduced during degradation or the contaminants are prevented to release. Another approach is using nanostructured membranes for air pollution control and capture of several pollutants like VOCs. Air filtration technology using antimicrobial nanoparticles is broadly applied to remove bioaerosols. Nanotechnology is also used to prevent the formation of pollutants or 
contaminants by creating an environmentally friendly substance or material, replacing widely used toxic materials, as well as reduced environmental impact. The nanotechnology also plays a promising and vital role in the improvement of rapid and accurate environmental process to decrease or prevent emissions or to convert contaminants to useful byproducts.

\section{Future Perspectives}

Throughout the world, there are numerous nanotechnology facilities and research team works. It is probably there is extensive duplication of research, and lack of communication. It is vital to orient research in relation to environmental pollution control issues by nanotechnology, and actively finding international partnerships, to realize the expected goals. In order turn this research into applications, there has to be an opportunity for developers to profit. This will depend on legislation/ fiscal laws, new, enviromental-friendly developments, thus providing the power for industry to rapidely bring urgently new products and processes to the market place. Nanotechnologies are important solution vectors in our economic environment. It is necessary to develop new methods to assess development for a better understanding of nanotechnology- based innovation.

Nanocatalysts for sustainable air purification are mostly still under development or just at the start of being ready for practical use. For catalysis research, the implications of further progress in nanocatalysis and the broad applications to the environment underscore the importance of this area for future investment. Science-based protocols to build and control composite particle structures should stimulate the development of improved methods for catalyst scale-up and large scale manufacturing that will be needed to broadly allow penetration of nano-engineered materials into new commercial catalyst applications. As a result, nano-materials and applications are already in the market and a large volume of new applications is expected over the next several years. The implementation of green chemistry principles for the production of nanoparticles must be grown markedly to create novel materials that are eco-friendly, cost effective and stable with great importance in wider application in the areas of environmental pollution remediation. Encouragement of optimal future use of nanotechnology in recycling approach of different wastes, this essentially means the use of wastes (whether gases, substances or whole products) to produce new materials or compounds that lead to an "industrial ecosystem" around the world. The final goal of future-nanotechnology ensuring sustainable optimal use of gases waste is to see the outputs of one production process become the inputs for another one in the industrial process chain.

\section{References}

Adeleye, A. S., Conway, J. R., Garner, K., Huang, Y., Su, Y., \& Kell, A. A. (2016). Engineered nanomaterials for water treatment and remediation: Costs, benefits, and applicability. Chemical Engineering Journal, 286, 640-662. https://doi.org/10.1016/j.cej.2015.10.105

Ai, Z., Ho, W., Lee, S., \& Zhang, L. (2009). Efficient photocatalytic removal of NO in indoor air with hierarchical bismuth oxybromide nanoplate microspheres under visible light. Environmental Science \& Technology, 43, 4143-4150. https://doi.org/10.1021/es9004366

Amade, R., Hussain, S., Ocana, I. R., \& Bertran, E. (2014). Growth and functionalization of 
carbon nanotubes on quartz filter for environmental applications. Journal of Environmental Engineering \& Ecological Science, 3(2), 1-7. https://doi.org/10.7243/2050-1323-3-2

Applications of Nanotechnology; International Society for Complexity, Information and Design (INCID): Altoona, PA, USA (2008). Available online: http://www.iscid.org/encyclopedia/Applications_of_Nanotechnology

Araújo, I. P. S., Costa, D. B., \& de Moraes, R. J. B. (2014). Identification and characterization of particulate matter concentrations at construction jobsites. Sustainability, 6, 7666-7688. https://doi.org/10.3390/su6117666

Azama, M. A., Aliasa, F. M., Tacka, L. W., Amalina, R. N., Mohamad, R. S., \& Taibb, F. M. (2017). Electronic properties and gas adsorption behaviour of pristine, silicon and boron-doped $(8,0)$ single-walled carbon nanotube: A first principles study. Journal of Molecular Graphics and Modelling, 75, 85-93. https://doi.org/10.1016/j.jmgm.2017.05.003

Bergmann, C. P., \& Machado, F. (2015). Carbon nanomaterials as adsorbents for environmental and biological applications. Carbon Nanostructures (Paulo Araujo, Tuscaloosa, AL, USA), Library of Congress, Springer Cham Heidelberg, New York, Dordrecht, London, Springer International Publishing, Switzerland. 1-126.

https://doi.org/10.1007/978-3-319-18875-1

Bhawana, P., \& Fulekar, M. H. (2012). Nanotechnology: Remediation technologies to clean up the environmental pollutants. Research Journal of Chemical Sciences, 2(2), 90-96.

Chirag, P. N. (2015). Nanotechnology: Future of environmental pollution control. International Journal on Recent and Innovation Trends in Computing and Communication, 3(2), 164-166.

Christensen, F. M., Brinch, A., Kjølhol, J. t, Mines, P. D., Schumacher, N., Jørgensen, T. H., \& Hummelshøj, R. M. (2015). Nano-enabled environmental products and technologies opportunities and drawbacks, The Danish Environmental Protection Agency, Copenhagen, DK (www.mst.dk).

Daly, A., \& Zannetti, P. (2007). An Introduction to Air Pollution-Definitions, Classifications, and History. Chapter 1: Ambient Air Pollution; Zannetti P., Al-Ajmi D. and Al-Rashied, S., Eds.; The Arab School for Science and Technology (ASST) and The EnviroComp Institute, Freemont, CA, USA, 1-14.

Das, S., Sen, B., \& Debnath, N. (2015). Recent trends in nanomaterials applications in environmental monitoring and remediation.Environmental Science Pollution Research International, 22(23), 18333-44. https://doi.org/10.1007/s11356-015-5491-6

Dong, H., Lin, B., Gilmore, K., Hou, T., Lee, S-T., \& Li, Y. (2015). B40 fullerene: An efficient material for $\mathrm{CO}_{2}$ capture, storage and separation. Current Applied Physics, 15, 1084-1089. https://doi.org/10.1016/j.cap.2015.06.008

Esrafili, M. D. (2017). $\mathrm{N}_{2} \mathrm{O}$ reduction over a fullerene-like boron nitride nanocage: A DFT study. Physics Letters A, 381(25-26), 2085-2091. 
https://doi.org/10.1016/j.physleta.2017.04.009

EPA (United States Environmental Protection Agency) (2017). Reviewing New Chemicals under the Toxic Substances Control Act (TSCA). Control of nanoscale materials under the toxic substances control act. Available

at:https://www.epa.gov/reviewing-new-chemicals-under-toxic-substances-control-act-tsca/con trol-nanoscale-materials-under (19 January 2017).

Falahi, H., \& Abbasi, A. M. (2013). Evaluate the effectiveness of nanotechnology in sustainable control of air pollution and reducing emissions. Technical Journal of Engineering and Applied Sciences, 3(S), 3904-3906.

Georgakilas, V., Perman, J. A., Tucek, J., \& Zboril, R. (2015). Broad Family of Carbon Nanoallotropes: Classification, Chemistry, and Applications of Fullerenes, Carbon Dots, Nanotubes, Graphene, Nanodiamonds, and Combined Superstructures. Chemical Reviews, 115, 4744-4822. https://doi.org/10.1021/cr500304f

Gillett, S. L. (2002). Nanotechnology: Clean Energy and Resources for the Future. Available at http://www.foresight.org/impact/whitepaper_illos_rev3.

Gupta, V. K., \& Saleh, T. A. (2013). Sorption of pollutants by porous carbon, carbon nanotubes and fullerene-an overview. Environmental Science and Pollution Research, 20, 2828-2843. https://doi.org/10.1007/s11356-013-1524-1

Hochella, M. F. Jr, \& Madden, A. S. (2005). Earth's nano-compartment for toxic metals. Elements, 1, 199-203. https://doi.org/10.2113/gselements.1.4.199

Heera, P., \& Shanmugam, S. (2015). Nanoparticle characterization and application: An overview. International Journal of Current Microbiology and Applied Sciences, 4(8), 379-386.

Hsu, S., \& Lu, C. (2007). Modification of single-walled carbon nanotubes for enhancing isopropyl alcohol vapor adsorption from water streams. Separation Science and Technology, 42, 2751-2766. https://doi.org/10.1080/01496390701515060

Herron, E. A., Kim, J., Upadhye, A. A., Huber, G. W., \& Maravelias, C. T. (2015). A general framework for the assessment of solar fuel technologies. Energy \& Environmental Science, 8, 126-157. https://doi.org/10.1039/C4EE01958J

Hulla, J. E., Sahu, S. C., \& Hayes, A. W. (2015). Nanotechnology: History and future. Human and Experimental Toxicology, 34(12), 1318-1321. https://doi.org/10.1177/0960327115603588

Hussain, Z., Ameer, A. A., Ahmed, A., Mudhaffar, Abdullah, B., \& Yousif, E. (2015). Nanotitanium dioxide as photocatalytic degradation of pollutants. Journal of Chemical and Pharmaceutical Research, 7(8), 522-530.

INPI - Instituto Nacional de Propriedade Intelectual. Nanotecnologia, (2009). 6.

ISO (International Organization for Standardization) (2010). ISO/DTS 80004-1 Nanotechnologies-Vocabulary-Part I: Core Terms, 16p. 
IPCC (2014). Climate Change 2014: Working group III contributing the fifth Assessment Report of the intergouvernmental panel on climate change-Mitigation of Climate Change, Combridge University press, $N Y$, pp.56.

Kim, J., Choi, S.-W., Lee, J.-H., Chung, Y., \& Byun, Y. T. (2016). Gas sensing properties of defect-induced single-walled carbon nanotubes. Sensors Actuators B: Chemical, 228, 688-692. https://doi.org/10.1016/j.snb.2016.01.094

Khan, I., Farhan, M., Singh, P., \& Thiagarajan, P. (2014). Nanotechnology for environmental remediation. Research Journal of Pharmaceutical Biological and Chemical Sciences, 5(3), 1916-1927.

Krug, H. F. (2009). Book Review Nanotechnology, Volume 2: Environmental Aspects, Chapter 9: Epidemiological Studies on Particulate Air Pollution. Environmental Engineering and Management Journal, 8(1), 191-194.

Lee, K. J., Shiratori, N., Lee, G. H., Miyawaki, J., Mochida, I., Yoon, S-H., \& Jang, J. (2010). Activated carbon nanofiber produced from electrospun polyacrylonitrile nanofiber as a highly efficient formaldehyde adsorbent. Carbon, 48(15), 4248-4255.

https://doi.org/10.1016/j.carbon.2010.07.034

Lee, B., Jung, J. H., \& Bae, G. N. (2010). Effect of relative humidity and variation of particle number size distribution on the inactivation effectiveness of airborne silver nanoparticles against bacteria bioaerosols deposited on a filter. Journal of Aerosol Science, 41, 447-456. https://doi.org/10.1016/j.jaerosci.2010.02.005

Logothetidis, S. (2012). Nanostructured Materials and Their Applications, NanoScience and Technology, Springer-Verlag, Berlin Heidelberg, Germany, 220.

https://doi.org/10.1007/978-3-642-22227-6

Long, R. Q., \& Yang, R. T. (2001). Carbon nanotubes as a superior sorbent for nitrogen oxides. Industrial \& Engineering Chemistry Research, 40, 4288-4291.

https://doi.org/10.1021/ie000976k

Loos, M (2015). Carbon nanotube reinforced composites, Chapter 1-nanoscience and nanotechnology, William Andrew Publishing, Oxford, pp 1-36.

Low, J., Cheng, B., \& Yu, J. (2017). Surface modification and enhanced photocatalytic $\mathrm{CO}_{2}$ reduction performance of $\mathrm{TiO}_{2}$ : a review. Applied Surface Science, 392(15), 658-686.

https://doi.org/10.1016/j.apsusc.2016.09.093

Mansoori G.A., Bastami T. R., Ahmadpour A., \& Eshaghi Z. (2008). Environmental Application of nanotechnology. Annual Review of Nano Research, 2(2), 1-73. https://doi.org/10.1142/9789812790248_0010

McMichael, A. J., Campbell-Lendrum, D. H., Corvalán, C. F., Ebi, K. L., Githeko, A. K., \& Scheraga, J. D. (2003). Climate change and human health: risks and responses. World Health Organization, Geneva, Chapter 2. Weather and climate: changing human exposures, 18-42. 


\section{Macrothink}

Environmental Management and Sustainable Development

ISSN 2164-7682

2017, Vol. 6, No. 2

Mehndiratta, P., Jain, A., Srivastava, S., \& Gupta, N. (2013). Environmental pollution and nanotechnology. Field Environment and Pollution, 2(2), 49-58.

https://doi.org/10.5539/ep.v2n2p49

Miyawaki, J., Lee, G-H., Yeh, J., Shiratori, N., Shimohara, T., Mochida, I., \& Yoon, S-H. (2012). Development of carbon-supported hybrid catalyst for clean removal of formaldehyde indoors. Catalysis Today, 185, 278-283. https://doi.org/10.1016/j.cattod.2011.09.036

Mukherjee, P. K. (2016). Nanomaterials: Materials with immense potential. Journal of Applicable Chemistry, 5(4), 714-7181.

Muralikrishnan, R., Swarnalakshmi, M., \& Nakkeeran, E. (2014). Nanoparticle-membrane filtration of vehicular exhaust to reduce air pollution - A review. International Research Journal of Environment Sciences, 3(4), 82-86.

Nanowerk. (2013). Nanotechnology in sports equipment: The game changer. Available at http://www.nanowerk.com/spotlight/spotid=30661.

Ngo, C., \& Van de Voorde, M. (2014). Nanotechnology in a Nutshell, Chapter 15: Nanotechnology Applications for Air and Soil, Atlantis Press, New Delhi, India, 267-282.

Özkar S. (2009). Enhancement of catalytic activity by increasing surface area in heterogeneous catalysis. Applied Surface Science 256(5), 1272-1277.

https://doi.org/10.1016/j.apsusc.2009.10.036

Petit, C., \& Bandosz, T. J. (2009). Graphite oxide/polyoxometalate nanocomposites as adsorbents of ammonia. Journal Physical Chemistry C, 113, 3800-3809.

https://doi.org/10.1021/jp8097044

Raj, B., Van de Voorde, M., Mahajan, Y., \& Ibram, Ganesh (2017). Nanomaterials for the conversion of carbon dioxide into renewable fuels and value-added products. Nanotechnology for Energy Sustainability. https://doi.org/10.1002/9783527696109

Ramsden, J. J. (2013). The nanotechnology industry. Nanotechnology Perceptions, 9, 102-118. https://doi.org/10.4024/N06RA13A.ntp.09.02

Ren, X., Chen, C., Nagatsu, M., \& Wang, X. (2011). Carbon nanotubes as adsorbents in environmental pollution management: a review. Chemical Engineering Journal, 170, 395-410. https://doi.org/10.1016/j.cej.2010.08.045

Ren, X., Li, J., Tan, X., \& Wang, X. (2013). Comparative study of graphene oxide, activated carbon and carbon nanotubes as adsorbents for copper decontamination. Dalton Transactions, 42, 5266-5274. https://doi.org/10.1039/c3dt32969k

Salthammer, T. (2016). Very volatile organic compounds: an understudied class of indoor air pollutants. Indoor Air, 26, 25-38. https://doi.org/10.1111/ina.12173

Sattler, K. D. (2010). Handbook of Nanophysics, Principles and Methods, CRC, New York, $1-23$. 
Scholten, E., Bromberg, L., Rutledge, G. C., \& Hatton, T. A. (2011). Electrospun polyurethane fibers for absorption of volatile organic compounds from air. ACS Applied Materials Interfaces, (3), 3902-3909. https://doi.org/10.1021/am200748y

Seredych, M., \& Bandosz, T. J. (2012). Manganese oxide and graphite oxide/ $\mathrm{MnO}_{2}$ composites as reactive adsorbents of ammonia at ambient conditions. Microporous and Mesoporous Materials, 150, 55-63. https://doi.org/10.1016/j.micromeso.2011.09.010

Shen, W., Zhang, C., Li, Q., Zhang, W., Cao, L., \& Ye, J. (2015). Preparation of titanium dioxide nanoparticle modified photocatalytic self-cleaning concrete. Journal of Cleaner Production, 87, 762-765. https://doi.org/10.1016/j.jclepro.2014.10.014

Singh, M., \& Naveen, B. P. (2014). Molecular Nanotechnology: A new avenue for environment treatment. IOSR Journal of Environmental Science, Toxicology and Food Technology, 8(1), 93-99. https://doi.org/10.9790/2402-08119399

Singh, S. B., \& Tandon, P. K. (2014). Catalysis: A brief review on nano-catalyst. Journal of Energy and Chemical Engineering, 2(3), 106-115.

Sofian, I., Harwin, Y., Kurniawan, A., Adityawarman, D., \& Indarto, A. (2012). Nanotechnologies in water and air pollution treatment. Environmental Technology Reviews, 1(1), 36-148.

Srivastava, V., Gusain, D., \& Sharma, Y. C. (2015). Critical Review on the Toxicity of Some Widely Used Engineered Nanoparticles. Industrial \& Engineering Chemistry Research, 54(24), 6209-6233. https://doi.org/10.1021/acs.iecr.5b01610

Su, F., Lu, C., Cnen, W., Bai, H., \& Hwang, J. F. (2009). Capture of $\mathrm{CO}_{2}$ from flue gas via multiwalled carbon nanotubes. Science of the Total Environment, 407(8), 3017-23.

https://doi.org/10.1016/j.scitotenv.2009.01.007

Terrones, M., Botello-Méndez, A. R., Campos-Delgado, J. et al. (2010). Graphene and graphite nanoribbons: morphology, properties, synthesis, defects and applications. Nano Today, 5(4), 351-372. https://doi.org/10.1016/j.nantod.2010.06.010

Tiwari, J. N., Tiwari, R. N., \& Kim, K. S. (2012). Zero-dimensional, one-dimensional, two-dimensional and three-dimensional nanostructured materials for advanced electrochemical energy devices. Progress in Materials Science, 57(4), 724-803.

https://doi.org/10.1016/j.pmatsci.2011.08.003

Wang, S., Sun, H., Ang, H. M., \& Tadé, M. O. (2013). Adsorptive remediation of environmental pollutants using novel graphene-based nanomaterials: Reviews in Chemical Engineering Journal, 226, 336-347. https://doi.org/10.1016/j.cej.2013.04.070

Wang, W., Liao, S., Liu, M., Zhao, Q., \& Zhu, Y. (2014). Polymer composites reinforced by nanotubes as scaffolds for tissue engineering. International Journal of Polymer Science, 2014, 1-14. https://doi.org/10.1155/2014/805634

Wagner, S., Gondikas, A., Neubauer, E., Hofmann, T., \& von der Kammer, F. (2014). Spot the 


\section{Macrothink}

Difference: Engineered and Natural Nanoparticles in the Environment-Release, Behavior, and Fate. Angewandte Chemie International Edition, 53, 12398-12419.

https://doi.org/10.1002/anie.201405050

Wu, S., He, Q., Tan, C., Wang, Y., \& Zhang, H. (2013). Graphene-based electrochemical sensors. Small, 9, 1160-1172. https://doi.org/10.1002/smll.201202896

Yadav, K. K., Singh, J. K., Gupta, N., \& Kumar, V. (2017). A review of nanobioremediation technologies for environmental cleanup: A novel biological approach. Journal of Materials and Environmental Sciences, 8(2), 740-757.

Ye, Y., Guo, Y., Yue Y., \& Zhang, Y. (2015). Facile colorimetric detection of nitrite based on anti-aggregation of gold nanoparticles. Analytical Methods, 7, 4090-4096.

https://doi.org/10.1039/C5AY00386E

Yu, B. F., Hu, Z. B., Liu, M., Yang, H. L., Kong, Q. X., \& Liu, Y. H. (2009). Review of research on air-conditioning systems and indoor air quality control for human health. International Journal of Refrigeration, (32), 3-20.

https://doi.org/10.1016/j.ijrefrig.2008.05.004

Zhang, X. X., Bing, Y., Dai, Z. Q., \& Luo, C. C. (2012). The gas response of hydroxyl modified SWCNTs and carboxyl modified SWCNTs to $\mathrm{H}_{2} \mathrm{~S}$ and $\mathrm{SO}_{2}$. Przeglad Elektrotechniczny, 88, 311-314.

Zhang, Y., Yuan, S., Feng, X., Li, H., Zhou, J., \& Wang, B. (2016). Preparation of nanofibrous metal-organic framework filters for efficient air pollution control. Journal of the American Chemical Society, 138, 5785-5788. https://doi.org/10.1021/jacs.6b02553

Zhao, Y-L., \& Stoddart, J. F. (2009). Noncovalent functionalization of single-walled carbon nanotubes. Accounts of Chemical Research, 42(8), 1161-1171.

https://doi.org/10.1021/ar900056z

Zaporotskova, I. V., Boroznina, N. P., Parkhomenko, Y. N., \& Kozhitov, L. V. (2016). Carbon nanotubes: Sensor properties. A review. Modern Electronic Materials, 2(4), 95-105.

https://doi.org/10.1016/j.moem.2017.02.002

Zhou, R., Hu, G., Yu, R., Pan, C., \& Wang, Z. L. (2015). Piezotronic effect enhanced detection of flammable/toxic gases by $\mathrm{ZnO}$ micro/nanowire sensors. Nano Energy, 12, 588-59. https://doi.org/10.1016/j.nanoen.2015.01.036

\section{Copyright Disclaimer}

Copyright for this article is retained by the author(s), with first publication rights granted to the journal.

This is an open-access article distributed under the terms and conditions of the Creative Commons Attribution license (http://creativecommons.org/licenses/by/3.0/). 